\title{
How does odor-specificity emerge in the olfactory system?
}

\author{
Ron A Jortner \\ From 1st International Workshop on Odor Spaces \\ Hannover, Germany. 4-7 September 2013
}

Olfactory systems operate in a balancing-act between two contrasting requirements. On the one hand, dealing with the bewildering repertoire of natural odors requires them to be extremely broad and versatile. At the same time, recognizing odors reliably, discriminating between similar compounds and overlapping mixtures, and detecting odorants in miniscule concentrations all require exquisite precision and specificity. How can a single system satisfy such opposite requirements?

There are of course specialized odorants (such as pheromones) which have highly specific receptor-proteins (and thus, highly specific receptor-neurons) tailored to them. In these cases the receptor-ligand pair implements a lock-and-key fit and downstream signaling proceeds via labeled-lines. Such specialized signaling channels, however, do not reflect the general case, and the designated hardware they require sharply limits the number of odorants which can be managed. General odorantsprocessed by general-purpose receptor neurons-pose a much bigger challenge, in that the very same hardware needs to allow both broadness and specificity.

Here I discuss how simple neuronal hardware can solve this complex task: generating arbitrarily odorspecific cells from an arbitrarily large odor input space. Experimental findings on network architecture in the olfactory system of the locust [1] were the inspiration for a highly simplified theoretical framework, key properties of which can be analytically solved [2]. I prove that an intermediate range of connectivity values between source- and target-populations leads to a combinatorial explosion of wiring possibilities, resulting in input spaces which are, by their very nature, exquisitely sparsely populated. In particular, connection probability $1 / 2$, as found in the locust antennal-lobe-mushroom-body circuit, maximizes separation of neuronal representations across the

\footnotetext{
MPI of Neurobiology - Department of Cellular and Systems Neurobiology,
} 82152 Martinsried, Germany

(c) 2014 Jortner; licensee BioMed Central Ltd. This is an Open Access article distributed under the terms of the Creative Commons Attribution License (http://creativecommons.org/licenses/by/2.0), which permits unrestricted use, distribution, and reproduction in any medium, provided the original work is properly cited. The Creative Commons Public Domain Dedication waiver (http:// creativecommons.org/publicdomain/zero/1.0/) applies to the data made available in this article, unless otherwise stated. target Kenyon cells, explaining their specific and reliable odor-responses. I show that combining such connectivity matrix with a suitable firing threshold generates arbitrarily odor-specific target cells: this forms a simple neuronal algorithm which is applicable to the general case of chemical sensing and may be found in other olfactory systems: it generates arbitrarily sparse and selective codes and allows to construct ecologically-meaningful representations from them.

Published: 16 April 2014

\section{References}

1. Jortner RA, Farivar SS, Laurent G: A simple connectivity scheme for sparse coding in an olfactory system. J Neurosci 2007, 27:1659-1669.

2. Jortner RA: Network architecture underlying maximal separation of neuronal representations. Front Neuroeng 2012, 5:19.

doi:10.1186/2044-7248-3-S1-O25

Cite this article as: Jortner: How does odor-specificity emerge in the olfactory system? Flavour 2014 3(Suppl 1):O25.

Submit your next manuscript to BioMed Central and take full advantage of:

- Convenient online submission

- Thorough peer review

- No space constraints or color figure charges

- Immediate publication on acceptance

- Inclusion in PubMed, CAS, Scopus and Google Scholar

- Research which is freely available for redistribution
() Biomed Central 